\title{
Developing a Framework for Analyzing Organizational Stories
}

\author{
Lin-Ping Lee, Hong-Wang Liu, Dong-Min Shi, \\ Christopher S.G. Khoo and Natalie Pang \\ Wee Kim Wee School of Communication \& Information, \\ Nanyang Technological University, Singapore 637718 \\ LEEL0038@e.ntu.edu.sg, \{W090008, W090009, assgkhoo, nlspang\}@ntu.edu.sg
}

\begin{abstract}
Stories are becoming an increasingly important knowledge management and knowledge sharing tool to communicate ideas, values and experiences both to internal organizational members and to external stakeholders. This paper reports an initial effort to develop a framework for the analysis of organizational stories. The framework has two major parts: the story framework comprising six elements, and the interaction/communication framework. A story analysis instrument was constructed based on the framework, comprising a series of questions to answer or a set of categories to select. The instrument was applied to twenty organizational stories, and was found to be easy to use and achieve good agreement across the coders. Relations between story type, knowledge embodied and story purpose were explored, and recommendations for crafting organizational stories are made.
\end{abstract}

\section{INTRODUCTION}

Organizational leaders use stories to espouse their vision and to promote expected organizational mindsets and behaviors. Richard Branson (2008), CEO of Virgin Group, used stories to communicate Virgin's philosophies about people, innovation, entrepreneurship, leadership and social responsibility. Bill Gates, founder of Microsoft, told stories of how Paul Allen and he made MS-DOS central to the IBM PC in 1980 (Heller, 2001).

Organizational stories are stories told about some aspect of the organization. They can provide an understanding of the cultural, political and emotional aspects of an organization. Stories transfer tacit knowledge and are often said to generate learning in the organization (Harris \& Barnes, 2006).

Organizational stories can also be everyday stories about the organization told by rank and file organizational members (Buskirk \& McGrath, 1992). Organizational stories can be directed at internal organizational members or to external stakeholders. They can be stories crafted by management to gain support for the company's initiatives or communicated to external stakeholders to build a certain image of the organization and its products.

Given the importance of storytelling as an organizational knowledge transfer mechanism, there is a need to develop a comprehensive and well-grounded framework for analyzing organizational stories to identify their salient characteristics, types of knowledge embodied and their likely effectiveness in achieving their purpose. This will help knowledge 
management and storytelling practitioners to evaluate stories and to craft stories for different organizational purposes.

This paper reports an initial effort to develop an organizational story analysis framework. The framework has two parts: a story framework developed through literature analysis, and an interaction/communication framework based on the work of Livo and Rietz (1986). Using the framework, twenty organizational stories were analyzed.

A story is generally defined as a series of related events that happen over time (Sax, 2006). Martens, Jennings and Jennings (2007) define stories or narratives as "temporally sequenced accounts of interrelated events or actions undertaken by characters" (pp. 11081109). Letiche, Boeschoten and de Jong (2008) suggested that narratives are "socially constitutive and performative" (p. 643). They contended that narratives do not simply reflect the real state of affairs but also mould, safeguard, enhance, decline and evade social groups. Fryer (2003) had a simpler perspective of stories, defining stories as simply expressing "how and why life changes" (p. 52). This study focuses on "organizational stories" which we define as a sequence of related events about the organization as a whole, organizational practices and processes, or organizational members.

\section{THE STORY ANALYSIS FRAMEWORK}

We developed a framework for the analysis of organizational stories through the lens of knowledge transfer. Boje (1991) defined a story as a transfer of experience between two parties. Riding on this element of storytelling, a major component of the framework is the transmittal of a story from a storyteller to the listener. The idea of stories as a knowledge transfer mechanism was held by Benjamin (2006) who defined stories as a way to move knowledge from one party to another and help the audience of the story to perceive and establish reality.

The framework aims to achieve the following in terms of its function as an analytical tool:

- Easily understood and easy to apply;

- Can account for different effects of different stories in different situations;

- Can be used to evaluate an organizational story in terms of effective transfer of knowledge, and achieving the aims of the storytelling.

The framework has two main parts:

1. The Story Framework (outlined in Figure 1) - the main elements of the story and its content, and the organizational context in which the story is told.

2. The Interaction/Communication Framework (outlined in Figure 2) - the interaction between the storyteller and listener(s), and the transmission of knowledge.

\section{Elements of a Story}

We divide the characteristics of a story into six elements:

1. Background to the story - the context in the story itself, including the prior situation and events leading up to the story.

2. Core of the story - the essence or summary of the story, or the story in its shortest and simplest form.

3. Structure of story-how the story is structured in terms of context, build up, climax, action, reversal, resolution and learning.

4. Type of story- the story is classified under a category in a typology. 


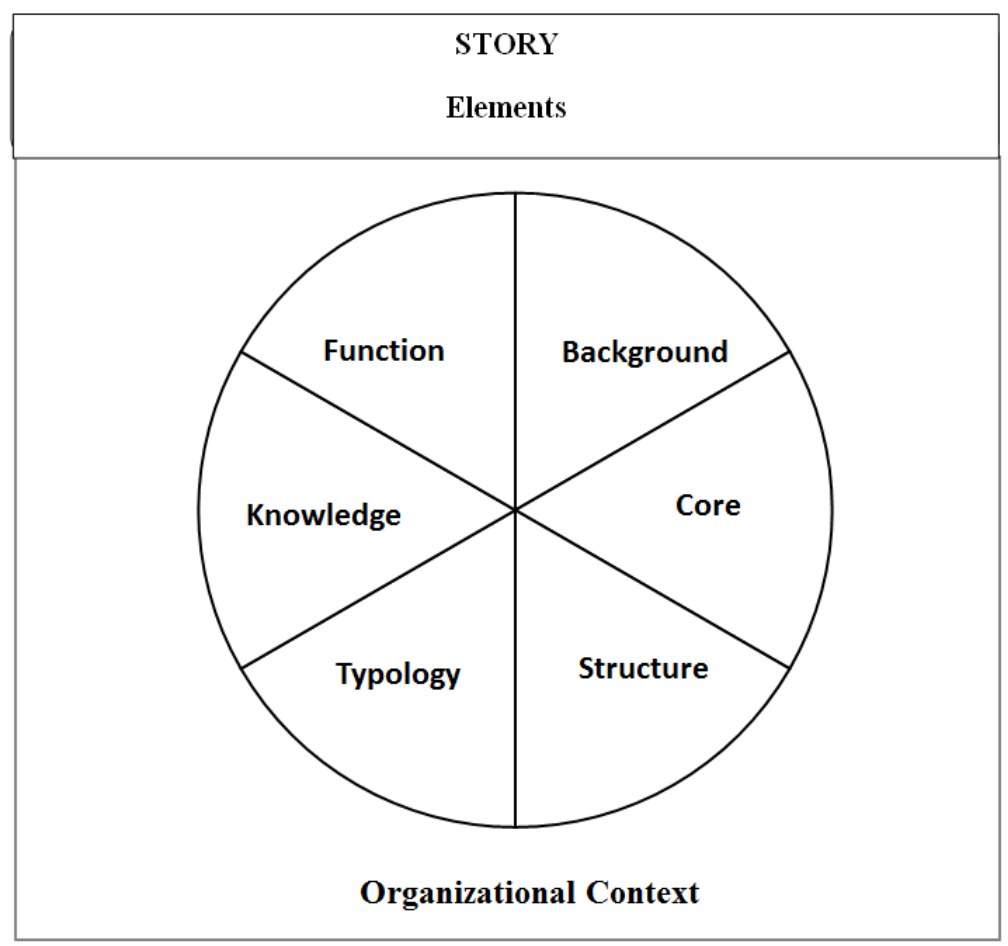

Figure 1. The Story Framework

5. Knowledge embodied in the story - the message or knowledge conveyed, or the moral of the story.

6. Function of the story-the purpose for which the story is told.

Underlying these six elements is the Organizational Context in which the story is told. An organizational story is told within a certain context to deliver a message relevant in the context. The message and elements of the story may differ when told in different contexts. A story may have different versions, with variation in the actors, time and location. However, the cause and sequence of events may be largely unchanged. This allows us to recognize them as different versions of the same story.

\section{Interaction/Communication Framework}

The interaction/communication part of the framework was conceptualized from the work of Livo and Rietz (1986). They stated that the interactive nature of the storytelling process is a dynamic that exists between the teller, listener and the story. This results in as many private story negotiations and reconstructions as there are listeners in the audience. The storyteller has his own view of the story told. The listener also has his own view of the story. In the course of storytelling, what the listener takes away from the story is influenced by his own experience, judgment and prejudices.

The interaction process which takes place during storytelling has three types of effects on knowledge transfer. These effects may occur simultaneously or asynchronously:

- Some part of the intended message is delivered: the knowledge which the storyteller intends to transmit is successfully absorbed by the listener.

- Some intended message is undelivered: part of the knowledge that the storyteller intended to transmit might not be absorbed by the listener due to his being unable to find the meaning in the story. 


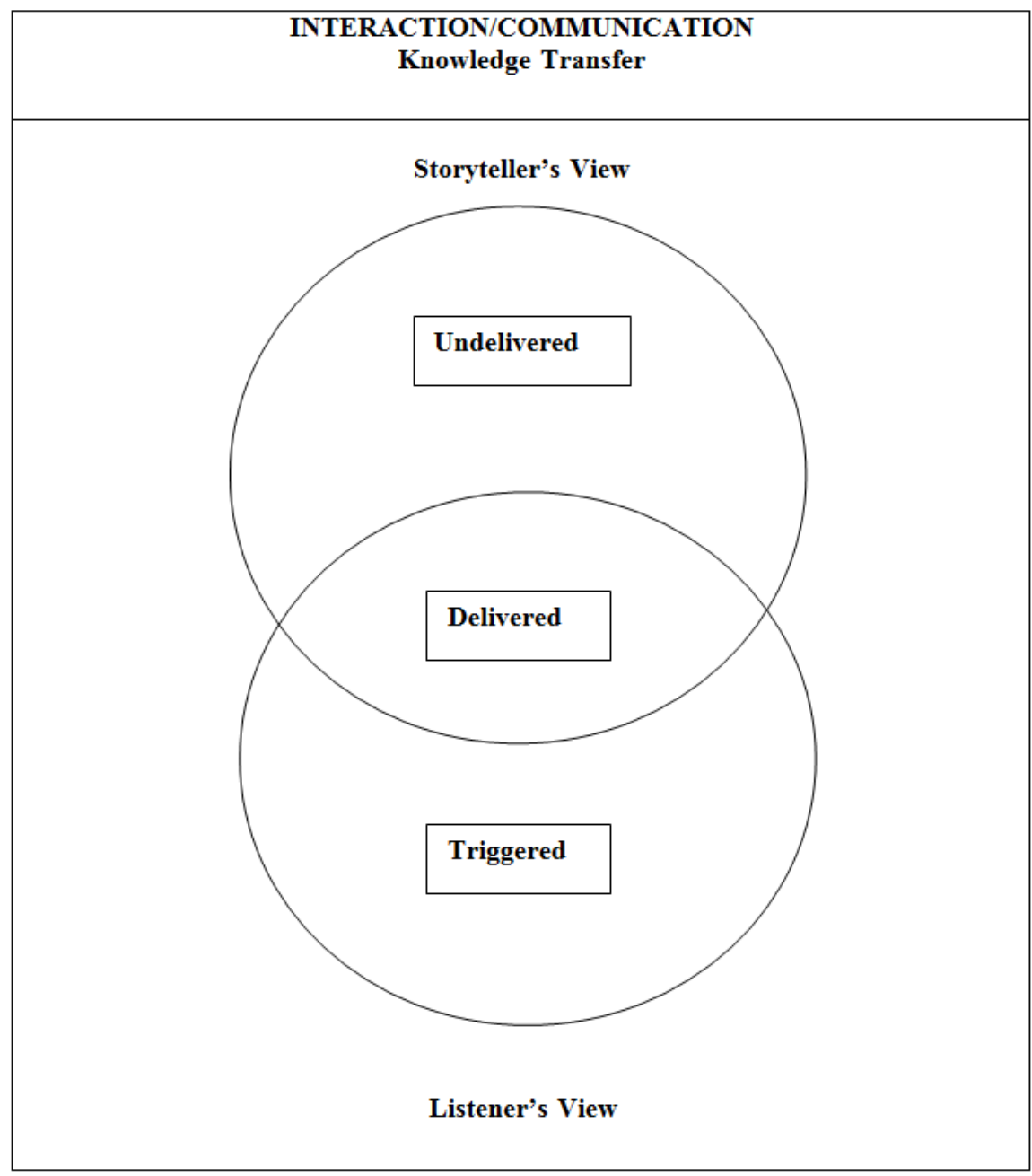

Figure2. The Interaction/Communication Framework

Some unintended message is triggered: Some knowledge or insight is triggered in the listener, which is not intended by the storyteller. This will vary from listener to listener due to differences in background, motivations and experiences.

\section{Story Analysis Instrument}

Based on the story framework's six elements, a story analysis instrument was constructed (see Table 1). For each element, there is a series of questions to be answered by the analyst. Some elements comprise a set of categories for the analyst to select one. Most of the questions in Table 1 are self-explanatory.

The typology of stories is derived from the work of Simmons (2006) and Neuhauser (1993). Of all the typologies suggested by researchers that we have reviewed, theirs are the most relevant and easy to understand. Their types of stories are listed in Table 2. 


\section{Table 1. The organisational story analysis instrument}

\section{Background to the story (Answer the following questions)}

- Organizational background: What is the type/industry/size of company?

- Event trigger: What happened to trigger the event

- Internal or external: Is the story targeted towards internal employees or external stakeholders?)

- Intention of the teller: What is the storyteller trying to convey? Why is he telling this story?

- First person or third person: Is the story told from a first person or third person perspective?

2. Core of the story (Answer the following questions)

A summary of the story in its simplest form - the essence of the story

- Actors: Who are involved in the story?

- Time: When did the story occur?

- Location: Where did the events take place?

- Event: What happened in the story?)

- Sequence: How did events in the story unfold?

- Cause: Why did the events happen?

3. Structure (sections) of the story (Answer the following questions)

- Context - In what situation did the story take place?

- Build up - What happened to lead up to the climax?

- Climax - What was the high point of the story?

- Action - What did the characters in the story do?

- Reversal - How did the situation change for the better or worse?

- Resolution - How was the situation resolved?

- Learning - What is the learning point of the story?

4. Type of story (Select one or more categories)

- Who I am story (helps the audience to perceive the storyteller in the light that the storyteller wants to be perceived.)

- Why I am here story (supplies credible reasons for the storyteller's positive motives.)

- Vision story (explains what the audience can get out of the storyteller's agenda and why they should allow his lead.)

- Values in action story (supplies instances to encourage internalization of desired values)

- Hero story (portrays organizational members who have displayed exemplary conduct and achieved exceptional performance.)

- Survivor story (regale listeners with how organizational members turn round a disastrous situation and set things back to normal.)

- Aren't we great story (showcase organizational achievements)

- Kick in the pants story (is used to provide early warning of potential disaster.) 


\section{Table 1 (cont.)}

5. Knowledge embodied in the story (Select one or more categories)

- Values (The attitudes the organization wants its employees to emulate and internalize)

- Behaviors (The ways in which the organization wants its employees to act)

- Norms (Social rules and standards of the organization)

- Experiences (Encounters in the past)

- History (The facts of the past)

6. Function (purpose/value) of the story (Select one or more categories)

- Spark organizational change

- Build trust

- Get individuals to work together

- Transmit values

- Tame the grapevine

- Share knowledge

- Create a future

Organizational stories are often told to advocate a point of view which puts the organization in a good light. There is some element of convincing and winning over others which makes the work of Simmons (2006) quite pertinent to our purpose. The "Who I am", "Why I am here", "The Vision" and "Values in action" stories are particularly relevant for classifying stories that communicate about the organization and what it stands for to external stakeholders. We decided not to adopt the category of "Teaching" stories as it overlaps with some of Neuhauser's (1993) categories, discussed in the next paragraph. We also left out "I know what you are thinking" category of stories as it is less a type of corporate story than a strategy by the storyteller to reach out to hostile listeners by acknowledging their adverse opinion.

Organizational stories are also told to internal employees to inspire them to higher performance, to teach organizational values, norms and expected behaviors and to learn from mistakes and avoid potential disasters. These are the strength of Neuhauser's (1993) typology. He categorized stories into two general types - positive and negative stories. A positive story is a constructive story that people can benefit from. For an organization, it means a positive outcome, for example an improvement in performance after hearing the story. His "Hero", "Survivor", "Aren't we great", and "Kick in the pants" categories are useful for classifying internal stories. We decided not to adopt "We know the ropes around here" as there is a degree of overlap with the "Aren't we great" stories, while the "Steam valve" stories defined by Neuhauser (1993) appear to serve a carthartic function of helping employees vent repressed negative feelings.

Our story structure elements are adapted from Snowden (2006) and Morgan and Dennehy (1997). Snowden's (2006) sequence of context, turning point, action, reversal and resolution appears useful for representing dramatic stories. However, organizational stories tend to have a buildup, a climax and should contain a lesson that is the main takeaway of the story. As such, we adopted some categories from Morgan and Dennehy's (1997) five steps to a story—setting (context), build up, climax, and learning. 
Table 2. Typologies of stories by Simmons (2006) and Neuhauser (1993)

\begin{tabular}{|c|c|}
\hline Types & Description \\
\hline \multicolumn{2}{|c|}{ Neuhauser's (1993) positive types of stories } \\
\hline Hero story & $\begin{array}{l}\text { How "the main character has done something beyond the normal } \\
\text { range of achievement and experience. ... who has given one's life to } \\
\text { something bigger than oneself" (quoted from Campbell, 1988). }\end{array}$ \\
\hline Survivor story & $\begin{array}{l}\text { "Everything went wrong ... and we fixed it" story. "We survived } \\
\text { against all odds." }\end{array}$ \\
\hline $\begin{array}{l}\text { Steam value story } \\
\text { (Letting off steam) }\end{array}$ & $\begin{array}{l}\text { Helps people to reduce stress and tension, and to build a feeling of } \\
\text { camaraderie and team loyalty. Often takes the form of "sick humor." }\end{array}$ \\
\hline $\begin{array}{l}\text { "Aren't we great" } \\
\text { Story }\end{array}$ & $\begin{array}{l}\text { Similar to the Survivor story, but delivered in a direct way telling the } \\
\text { audience with pride, enthusiasm and sometimes exaggeration how } \\
\text { great they are. }\end{array}$ \\
\hline $\begin{array}{l}\text { "We know the ropes } \\
\text { around here" story }\end{array}$ & $\begin{array}{l}\text { Story about an individual or team with a high level of technical job } \\
\text { skills combined with a high degree of organizational political savvy, } \\
\text { who can get ideas or changes through the bureaucracy and } \\
\text { personalities of the organization. }\end{array}$ \\
\hline $\begin{array}{l}\text { Kick in the pants } \\
\text { story }\end{array}$ & $\begin{array}{l}\text { Tells of dangers, mistakes, or shortsightedness. The message is that } \\
\text { the company or individuals are headed for trouble if they do not } \\
\text { change their ways. }\end{array}$ \\
\hline \multicolumn{2}{|c|}{ Simmons' (2006) types of stories } \\
\hline "Who I am" story & $\begin{array}{l}\text { Helps the audience to perceive the storyteller as the storyteller wants } \\
\text { to be perceived. Reveal an aspect of the storyteller to persuade the } \\
\text { audience that he is trustworthy. }\end{array}$ \\
\hline $\begin{array}{l}\text { "Why I am here" } \\
\text { story }\end{array}$ & $\begin{array}{l}\text { Provides credible reasons for the storyteller's good intentions. "What } \\
\text { is in it for you? What do you gain from this?" }\end{array}$ \\
\hline Vision story & $\begin{array}{l}\text { Explains what the audience can get out of the storyteller's agenda and } \\
\text { why they should allow his lead. Communicates the vision in a way } \\
\text { that connects with the audience. }\end{array}$ \\
\hline Teaching stories & $\begin{array}{l}\text { Helps the audience to make sense of new skills in meaningful ways. } \\
\text { Situates a skill in context, in its complexity. }\end{array}$ \\
\hline $\begin{array}{l}\text { Values in action } \\
\text { story }\end{array}$ & $\begin{array}{l}\text { Teaches a value by example. Provides evidence to encourage } \\
\text { internalization of desired values. }\end{array}$ \\
\hline $\begin{array}{l}\text { "I know what you } \\
\text { are thinking" story }\end{array}$ & $\begin{array}{l}\text { Reveals the storyteller's awareness of possible opposing views and to } \\
\text { bring these views out in the open before they can fester into problems. }\end{array}$ \\
\hline
\end{tabular}

These categories or stages in a story are quite abstract and generic. From an extensive analysis of hundreds of stories over a 34-year period, Booker (2004) identified seven basic story plots or patterns that kept recurring:

1. Overcoming the monster

2. Rags to riches 
3. The quest

4. Voyage and return

5. Comedy

6. Tragedy

7. Rebirth.

The stages in Booker's plots are more nuanced than the generic categories that we have adopted, though most of them can be subsumed under our generic categories. For example, Booker's Rags to riches story plot has the stages:

1. Initial wretchedness at home and the "Call" (i.e. context)

2. Out into the world, initial success (build-up)

3. The central crisis (reversal)

4. Independence and the final ordeal (action + climax)

5. Final union, completion and fulfillment (resolution + learning).

It is not known which of the seven plots are used or useful in organizational stories. We shall leave this issue to a future study.

Organizational stories are told to share successful experiences, build culture, pass down history or learn from failure. Thus, our analysis instrument seeks to identify the following kinds of knowledge embodied in stories:

1. Values: The attitudes the organization wants its employees to emulate and internalize

2. Behaviors: The ways in which the organization wants its employees to act

3. Norms: The social rules and standards of the organization

4. Experiences: Lessons from past encounters

5. History: The facts of the past, and milestones in the organization's development.

The final part of our story analysis instrument requires the analyst to categorize the stories according to Denning's (2004) seven functions (purpose/value) of organizational stories. Other typologies were found to be too vague or general for our purpose. Denning's functions are broad categories compared to the story types defined by Simmons (2006) and Neuhauser (1993). As such, different types of stories may have the same function. For example, stories to spark organizational change might be a "vision" or "kick in the pants" story depending on the content of the story.

\section{ANALYSIS OF ORGANIZATIONAL STORIES}

We applied the instrument to analyze twenty stories to find out whether the instrument was usable, any difficulties in applying it, and relationship between type of story, function and type of knowledge embodied in the story. We sourced for organizational stories in books and the Internet. Fourteen of the stories were taken from books by Fog, Budtz \& Yakaboylu (2005), Denning (2001 \& 2005), Gargiulo (2005), Owen (2004), and Smith (2012). Six stories were taken from the following websites:

- Changing Minds.org (http://changingminds.org/disciplines/storytelling/organizations/storytelling_organizations. $\underline{\mathrm{htm}})$

- About.com (http://inventors.about.com/od/pstartinventions/a/post it note.htm)

- The New Yorker online magazine (http://www.newyorker.com/magazine/2011/10/17/how-steve-jobs-changed)

- Lean In website (http://leanin.org/stories/ursula-burns/)

- Digitoe website (http://www.digitoe.com/short_stories/) 
- Marketing Week online magazine (http://www.marketingweek.co.uk/trends/case-studypatagonias-dont-buy-this-jacket-campaign/4005451.article)

We selected a variety of stories, with at least one example for each type of story and each type of function in our story analysis instrument. Some stories were told from the management point of view, some from the perspective of the rank and file organizational members, and some from an industry perspective. The story length was limited to two pages (below 1000 words). Organizational stories are usually told verbally and in snapshots to bring across a point. As such, they should not be too lengthy and take up too much time when they are being told. The stories chosen also reflect different cultural and organizational backgrounds, from small enterprises to national enterprises and international organizations such as The World Bank and IBM. An example for each type of story is provided in the Appendix. Due to space constraint, only abstracts of the stories are given.

Each story was analyzed and coded by three of the authors. Multiple categories were allowed to be assigned for story type, knowledge embodied and function of story. There was good agreement in the analyses across the coders. For the elements of story type, type of knowledge and function, each coder had assigned at least one category in common with another coder, for most of the stories. For a majority of the stories, there was at least one category assigned by all three coders.

\section{Frequently Assigned Categories and Categories That Tend to be Assigned Together}

As multiple categories were allowed in the coding, the majority of the stories were assigned two or three story types, types of knowledge embodied and functions of the story. This suggests that the categories overlap to some extent, and that stories can have multiple interpretations and can serve multiple functions.

For each story, we accepted as correct the categories (for story type, knowledge type and function type) that were assigned by at least two coders. We analyzed them to identify the categories that were associated-i.e. that tended to be assigned together.

\section{Type of story}

The selection of stories did not follow random sampling, as we attempted to include a variety of stories with different attributes. Nevertheless some types of organizational story were easier to find than others. The frequencies of the story categories in the sample reflect to some extent the ease of locating the various types of stories. The most common types of story in the sample were:

- Values in action (8 stories)

- Kick in the pants (7 stories)

- Hero (6 stories)

- Who I am (6 stories).

Espousing and illustrating particular values (personal and organizational values) is a particular strength of stories. Hence, Values in action stories are relatively common. Kick in the pants stories are cautionary stories that are also used to promote particular values or behaviors. Hero stories are often origin stories that tell how the organization started or stories of extraordinary accomplishment because of certain desirable values or behavior of the protagonist. Who I am stories are told by leaders to increase trust in the leader, and may be used to promote a direction or vision for an organization. 
A Who I am story usually shows the storyteller in a positive light, as a hero or survivor, and is thus sometimes assigned together with the Hero or Survivor category. Who I am story is also sometimes a Why I am here story, as Who I am can suggest reasons for Why I am here.

\section{Type of knowledge embodied}

The most frequently assigned types of knowledge were:

- Values (12 stories)

- Behaviors (7 stories)

- Experiences (7 stories)

- History (4 stories).

The category Values (the attitudes the organization wants its employees to have) was assigned together with Behaviors (the ways the organization wants its employees to act) for six stories. In three of the instances, Norms was also assigned. These three types of knowledge-Values, Behaviors and Norms — are clearly associated: an organization's values affect the behavior of its members, and habitual behavior results in social norms.

Values was also often assigned together with Experiences (11 stories), and History (11 stories). Experiences tended to be assigned for the experiences of individuals, whereas History tended to be assigned when the focus was on organization's origin and development.

\section{Function of story}

The most common function (or purpose) assigned were:

1. Transmit values (13 stories)

2. Share knowledge (7 stories)

3. Spark organizational change (6 stories)

4. Create a future (5 stories).

Transmit values is almost the default function of organizational stories. If a story has a cultural element, then the story tends to be seen as having the function of transmitting values. Share knowledge seems to be a miscellaneous category: when a story doesn't have a clear function, it can be categorized as conveying some kind of knowledge.

\section{Function of a Story and its Relation With the Story Type and Type of Knowledge Embodied}

Denning (2004) noted that "different narrative objectives had different narrative patterns associated with them", and that "using the wrong form of story for a particular purpose generally led to an unsuccessful result" (p. xv). We analyzed the relation between story type, knowledge embodied and function of the story. Because of the small sample, we can only offer conjectures to be verified in bigger scale studies.

The following functions were associated with particular story types or knowledge types:

- Transmit values: stories assigned this function tended to be Values in action type of story (7 instances in the sample), and have Values (12 stories) or Behaviors (4 stories) as the embodied knowledge. This is not surprising as a particular strength of stories is to convey values by describing behaviors/actions that reflect those values, and pointing out desirable consequences of these behaviors.

- Share knowledge: this function is associated with Experiences (12 stories) and History (4 stories) as the knowledge embodied. Experiences refer to knowledge derived from an 
individual's experience, whereas History refers to the origin and development of the organization.

- Create a future: this function is associated with the Vision story (4 stories), which envisions a future that is not yet realized - based on a seminal event in the same organization, or a surprising event in another organization. This function can also be associated with an individual who has a leadership role (Who am I story), or who exemplifies a direction for the organization (Hero story).

- Spark organizational change: this function can be implemented using a wide range of story types. In the sample, it is co-assigned with the following story types: Values in action, Hero, Who I am, Vision, Survivor, and Kick in the pants.

- Build trust: this function is associated with the Who I am, Why I'm here, and Survivor stories. It is also associated with the Experiences type of knowledge.

There were not enough stories that were assigned the functions of Get individuals to work together and Tame the grapevine to derive associations with story types and types of knowledge.

\section{CONCLUSION AND FUTURE WORK}

This paper has proposed a framework to help knowledge management professionals analyze organizational stories, and identify their main features. A story analysis instrument was constructed based on the framework. It comprises a series of questions to answer or a set of categories to select for the six elements of the framework. The framework was applied to twenty organizational stories, and was found to be easy to use and achieve good agreement across the coders.

An analysis of the categories assigned for story type, type of knowledge embodied and function of story yielded some insights. In the crafting of organizational stories, the knowledge to be transferred and the type of story to be told is determined to a large extent by the purpose of the story. For stories told to transmit values, the knowledge embodied tends to be values or desirable behaviors (actions), and they are usually values-in-action stories that tell of organizational members behaving in ways that actualize these values. If the purpose of the story is to share knowledge, the knowledge embodied in the story is usually personal experiences with a learning point, or events in the history of the organization. Vision stories are told to envisage a future and direction for the organization. This is facilitated by a Who I am story to engender trust in a leader, or a Hero story to raise a flag at the pinnacle! Organizational stories that are meant to spark organizational change or build trust have a more diverse typology.

The same organizational story should be crafted differently if they are to be told in different contexts to different audiences for different purposes. Several versions of the same story can be developed to deliver different messages. Although the gist of the story remains the same, there should be differences in the emphasis of the content and the way the message is couched. It is also recommended that due to differences in background, motivations and experiences on the part of the listener, the organizational story to be crafted should contain a paragraph or sentence that highlights the message to be delivered in a clear and coherent manner.

The main limitations of this study are the small sample of stories, the small number of coders, and our inability to carry out random sampling of stories, as there is no one good source of organizational stories and the stories had to be collected by browsing diverse 
sources. An in-depth qualitative study is needed to investigate how users interpret and categorize organizational stories, and derive messages and knowledge from them.

Further research is needed to develop the story framework and analysis instrument in greater depth. In particular, the framework raises the following questions:

1. How are different story backgrounds important? Are there additional elements that are important?

2. What is the core of a story, and how can this be identified? We expect the story core to be a graded concept, i.e. some details of a story will be more core than others. We are carrying out a study to identify the core aspects of sample stories through user recall and recognition. We are also analyzing different versions of the same story to identify the core aspects.

3. In the analysis instrument, we have listed the types of stories, elements of story structure, types of knowledge embodied and types of functions. However, it is not known how complete the categories are, and whether the listed categories are a good way to identify similar and different kinds of organizational stories.

4. Though the framework is able to identify the salient features of a story and its main message and purpose, it is not yet able to determine what makes a good organizational story. Research is needed to identify what makes a good or effective organizational story compared to a less effective one, and how the different elements in the framework contribute to a good story.

5. The Interaction/Communication Framework needs further fleshing out. It is not clear what factors determine what intended knowledge is delivered and what unintended knowledge is triggered.

6. It is not known which of the Booker's (2004) seven basic plots are useful in organizational stories, and how they relate to the different types and functions of stories. We hypothesize that the Overcoming the monster plot is associated with Survivor stories, the Rags to riches plot with the Who I am and Why I am here stories, The quest with Hero stories, Voyage and return with Vision story, Comedy with Values in action story,

Tragedy with Kick in the pants story, and Rebirth with Who I am and Survivor stories.

Future work can also examine the effect of stories delivered through different media and communication channels. A story delivered in verbal, written and video form may elicit different interpretations and have different impact.

\section{REFERENCES}

Benjamin, B. (2006). The Case Study: Storytelling Beyond the Industrial Age and Beyond. On the Horizon, 14(4), 159-164.

Boje, D. (1991). Consulting and Change in the Storytelling Organization. Journal of Organizational Change Management, 4 (3), 7-17.

Booker, C. (2004). The seven basic plots: Why we tell stories. London: Continuum.

Branson, R. (2008). Business Stripped Bare: Adventures of a Global Entrepreneur. London: Virgin Books.

Buskirk, W., \& McGrat, D. (1992). Organizational Stories as a Window on Affect in Organizations. Journal of Organizational Change Management, 5(2), 9-24.

Campbell, J. (1988). The power of myth. New York: Doubleday

Cognitive E. (2006). Story Construction. Retrieved on July 21, 2010, from http://www.cognitive-edge.com/files/ StoryConstructionMethodDocument.pdf 
Copies in seconds: how a lone inventor and an unknown company created the biggest communications breakthrough since Gutenberg / David Owen.

Czarniawska-Joerges, B. (1998). A narrative approach to organization studies. Thousand Oaks, CA: Sage.

Denning, S. (2001). The Springboard: How storytelling ignites action in knowledge-era organizations. Butterworth Heinemann.

Denning, S. (2004). Squirrel inc.: a fable of leadership through storytelling. Jossey-Bass A Wiley.

Denning, S. (2005). The leader's guide to storytelling: Mastering the art and discipline of business narrative. Squirrel Inc.

Fog, K., Budtz, C., \& Yakaboylu, B. (2005). Storytelling Branding in Practice. Berlin: Springer.

Fog, K., Budtz, C., \& Yakaboylu, B. (2005). Storytelling branding in practice. Berlin: Springer.

Fryer, B. (2003). Storytelling that moves people: A conversation with screenwriting coach Robert McKee. Harvard Business Review, 81(6), 51-55. Retrieved August 15, 2014 , from: http://hbr.org/2003/06/storytelling-that-moves-people/ar

Gargiulo, T.L. (2005). The strategic use of stories in organizational communication and learning. Armonk, NY: M.E. Sharpe.

Harris, J. \& Barnes, K.B. (2006). Leadership Storytelling, Industrial and Commercial Training, 38(7), 350-353.

Heller, Robert. (2001). Roads to Success. New York : Dorling Kindersley.

Letiche, H., Boeschoten, R., \& de Jong, F. (2008). Workplace learning: Narrative and professionalization. Journal of Organizational Change Management, 21(5), 641-654.

Livo, Norma J. and Rietz, Sandra A. (1986). Storytelling: process and practice. Littleton, CO: Libraries Unlimited.

Martens, M.L., Jennings, J.E., \& Jennings, P.D. (2007). Do the stories they tell get them the money they need? The role of entrepreneurial narratives in resource acquisition. Academy of Management Jourmnal, 50(5), 1107-1132.

Morgan, S., \& Dennehy, R.F. (1997). The Power of Organizational Storytelling: A Management Development Perspective. Journal of Management Development, 16(7), 494-501.

Neuhauser, P.C. (1993). Corporate Legends and Lore: The Power of Storytelling as a Management Tool. New York: McGraw-Hill, Inc.

Owen, D. (2004). Copies in seconds: How a lone inventor and an unknown company created the biggest communication breakthrough since Gutenberg: Chester Carlson and the birth of the xerox machine. New York: Simon and Schuster.

Ready, D.A. (2002). How Storytelling Builds Next Generation Leaders. MIT Sloan Management Review, 43(4), 63-69.

Sax, B. (2006). Storytelling and the' Information Overload, On the Horizon, 14(4) 165-170.

Simmons, A. (2006). The Story Factor: Inspiration, Influence and Persuasion Through the Art of Storytelling. Basic Books.

Smith, P. (2012). Lead with a story: A guide to crafting business narratives that captivate, convince, and inspire. New York: American Management Association. 


\section{Appendix. Examples of Organizational Stories Used in this Study}

1. The TDC Story (Source: Fog, Budtz \& Yakaboylu, 2005)

Summary: Denmark's largest mobile phone operator, TDC Mobile tried to introduce the company's new name: VIC to its customers. The campaign was launched with a story that succeeded in creating curiosity. Unfortunately, it stopped there. The story had not been integrated into the long-term branding platform. People were confused. TDC's attempt to create added value and build an emotional bond with customers that could differentiate the VIC brand from other mobile phone operators on the market, had failed. TDC Mobile soon afterwards, dropped any further work with the VIC name.

Type of story: Kick in the pants

Type of knowledge embodied: Experiences

Function/purpose of story: Share knowledge

\section{The IBM \$10M failure Story (Source:}

http://changingminds.org/disciplines/storytelling/organizations/failure_stories.htm)

Summary: A senior employee of IBM made a $\$ 10 \mathrm{M}$ error. He was hauled up before the big boss where he expected to be sacked. Pre-empting this, he apologized and offered his resignation. Refusing the resignation, the boss said he couldn't lose him now, because the company just spent $\$ 10 \mathrm{M}$ on his education.

Type of story: Values in action

Type of knowledge embodied: Values

Function/purpose: Transmit values

\section{The Yemen Story (Source: Denning, 2001)}

Summary: A member of a task team was working with a client in Yemen on an education project and was coming to the end of its visit. The client asked for urgent advice which he was unable to provide. The team was unable to provide that advice so it contacted the Help Desk of the Education Sector. The Help Desk got in touch with their CoP. The CoP realized similar work had been done in Kenya. Results of the work in Kenya were faxed to Yemen. The team in Yemen was able to advise their client in 48 hours.

Type of story: Survivor, Vision, Hero

Type of knowledge embodied: Experiences, Values

Function/purpose: Create future, Spark organizational change, Transmit values

4. The World Bank Story (Source: Denning, 2005)

Summary: The World Bank was facing strong competition from private banks. At the same 
time, Denning was not doing well in his career and senior management told him to look at information. Denning thought of selling expertise of the World Bank but he was not getting much support from some of his colleagues initially. He started to find a way how he was going to persuade this organization to change. He finally got the support he needed when he explained Knowledge Management through the use of stories. The World Bank was doing well as a lending organization and Denning wanted to move the World Bank to a new line of business that deals with knowledge.

Type of story: Who I am

Type of knowledge embodied: Experiences, History

Function/purpose: Spark organizational change, Share knowledge

\section{3M Post-it Notes (Source:}

http://inventors.about.com/od/pstartinventions/a/post_it_note.htm)

Summary: Spencer Silver invented an adhesive in 1968 but it was rejected by 3M. 5 years later, Art Fry attended one of Spencer Silver's seminars and used the adhesive on Post-it notes. Art Fry found the Post-it notes useful as 'reusable bookmarks' in his hymnal. He sees the potential of the Post-it notes in being a viable product. Art Fry tries to win support from $3 \mathrm{M}$ for the Post-it notes. Art Fry's superiors were initially worried that consumers would consider Post-it notes to be wasteful, but they eventually gave it their support after samples of the product distributed to $3 \mathrm{M}$ employees proved wildly popular. Post-it notes were introduced across the country in 1980 and proved to be a worldwide success less than 2 years later.

Type of story: Hero, Values in action

Knowledge embodied: History, Values

Function/purpose: Share knowledge, Transmit values

\section{Ursula Burns Story (Source: http://leanin.org/stories/ursula-burns/)}

Summary: I was raised by a wonderful mother in the rough and tumble public housing projects on the lower east side of Manhattan. Many people told me I had three strikes against me. I was black. I was a girl. And I was poor. ... My life since then has been a series of lean in moments: taking an internship with Xerox in upstate New York, going to an Ivy League school for a graduate degree, signing on with Xerox, and climbing the ladder to the top. Dreams do come true, but not without the help of others, a good education, a strong work ethic and the courage to lean in. That's why I spend so much time with organizations that help minorities and women gain the education and self-respect they need to take risks, to dream big and, hopefully, to someday pay it forward.

Type of story: Who I am, Why I am here, Vision, Hero Knowledge embodied: Values, Experiences

Function/purpose: Build trust, Transmit values, Create a future 
7. Patagonia's 'Don't buy this jacket' Campaign (Source:

http://www.marketingweek.co.uk/trends/case-study-patagonias-dont-buy-this-jacketcampaign/4005451.article)

Summary: Patagonia has strived to remain true to its eco-friendly ethos by using organic cotton and recycled polyester in its products and by urging consumers to consider the environmental effect of their purchases. In the run-up to Christmas, the brand ran a poster and PR campaign that told customers 'Don't buy this jacket'. The message was intended to encourage people to consider the effect of consumerism on the environment and purchase only what they need. "We're at the opposite spectrum of big brand disposable fashion," explains Petty. "We're about making great quality products that are designed to last, so we have a lifetime warranty on our products."

Type of story: Vision, Values in action, Aren't we great Knowledge embodied: Values, Behaviors, Norms

Function/purpose: Transmit values, Create a future 